\title{
The Influence of Classroom Management toward Students' English Achievement at SMU Muhammadiyah Salatiga (A Case Study of Second Year Students of SMU Muhammadiyah Salatiga in the Academic Year of 2004/2005)
}

\section{Triyono}

State Institute of Islamic Studies (STAIN) Salatiga

Jl. Tentara Pelajar No. 2 Salatiga, Central Java, Indonesia

Triyono03@gmail.com

\begin{abstract}
This research aims to find out the influence of classroom management toward students' achievement in English. The research was conducted at SMU Muhammadiyah Salatiga, Central Java, Indonesia. The writer focuses on the second year students in the academic year of 2004/2005. It is a Quantitative Research. Questionnaire and direct observation are the instruments used to take the data. The score of classroom management of SMU Muhammadiyah Salatiga is $87.6 \%$, fairly high. While the score level of the second year students of SMU Muhammadiyah Salatiga is $72 \%$. This score level is satisfactory category of achievement level of most students. It means that better classroom management influences better English achievement.
\end{abstract}

Keywords: Classroom Management, Achievement, SMUMuhammadiyah

\section{Abstrak}

Penelitian ini bertujuan untuk mengetahui pengaruh manajemen kelas terhadap prestasi siswa dalam bahasa Inggris . Penelitian ini dilakukan di SMU Muhammadiyah Salatiga , Jawa Tengah, Indonesia . Penulis fokus pada siswa tahun kedua pada tahun akademik 2004/2005. Ini adalah Penelitian kuantitatif yang menggunakan kuesioner dan observasi langsung sebagai instrumen pengambilan data. Hasil penelitian menunjukkan bahwa nilai pada pengelolaan kelas SMU Muhammadiyah Salatiga cukup tinggi, yaitu 87,6\%. Sementara tingkat skor mahasiswa tahun kedua adalah $72 \%$. Level skor ini termasuk dalam kategori memuaskan dalam 
pencapaian sebagian besar siswa. Ini berarti bahwa manajemen kelas yang lebih baik mempenganuhi prestasi Bahasa Inggris menjadi lebih baik pula.

Kata Kunci : Manajemen Kelas, Prestasi, SMU Muhammadiyah

\section{Introduction}

The primary task of a teacher is to educate. Education is an activity done consciously to develop students' potential and change self-quality from a low quality to high one (Pasaribu and Simanjuntak, 1983: 7). Students are human beings who need help in order that their potential can be developed harmoniously. In addition, the other assignment of teacher is enhancing students' motivation to learn (Jones and Jones, 1981: 163). Low motivation, negative self-attitude, and failure are largely the result of improper leaming condition. We should be able to alter students' failure rate by changing the condition of classroom learning and as consequence increasing their motivation to succeed.

Teaching is a complex process that can be conceptualized in a number of different ways. Traditionally, language teaching been described in terms of what teacher does, which are the actions and behaviors which teacher carries out in the classroom and the effect of those on leamers (Richard and Lockhard, 1994: 32). Many problems are faced in teaching leaming process especially for teachers who are responsible to make students understand the materials, to control classroom atmosphere so students feel enjoying and happy in leaming process; and succeed in their study. One teacher's roles in teaching leaming process is a teacher as manager ( Usman, 1990: 4). This means that in teaching learning process, a teacher must be able to 
manage classroom, to control classroom every time and the convertible situation to make the students enjoy the lesson; and the most important thing is that they understand the materials. Beside those a teacher has many kinds of tasks which must be done in the classroom such as selecting leaming activities, preparing materials, presenting learning activities, asking question, checking students' understanding, monitoring students' leaming, and giving feedback on students' leaming.

Classroom management skills are important point in determining a successful teaching. Thus, management skills are crucial and fundamental. In the classroom management, there are three areas of expertise needed in the beginning of teaching:

a. Knowledge of how to manage a classroom

b. Mastering of subject matter

c. Understanding of their students' sociological and psychological background.

According to Wadd one of components which make successful in teaching learning process is resources of power. This is to organize all aspects of work in the classroom and has contribution more significantly to extent of the teacher's effectiveness. Teacher's effectiveness is usually measured by the ability to teach and to mange students' group in the classroom. They should become effective teachers that are responsible for making students have high achievement. They must know how to manage lesson, how to manage students, how to use method at that is appropriate with the materials, and how to interact with students in classroom activities.

The objectives of the study are: (1) to find out the pattern of classroom management in teaching leaming process of the second year students of SMU Muhammadiyah Salatiga. (2) To prove 
whether classroom management influences students' achievements significantly. (3) To prove that classroom management in teaching learning process has significant contribution to the students' English achievement of the second year of SMU Muhammadiyah Salatiga.

\section{Research Methodology}

The writer uses certain research methodology covering research design, technique of data collection, research procedures, data presentation, and the method of data analysis and questionnaire result.

\section{Research Design}

The writer conducts the questionnaire that is about Classroom Management as Independent variable to the students of SMU Muhammadiyah Salatiga to collect data. The writer takes 30 students of second years at SMU Muhammadyah Salatiga in academic 2004/2005. Objects of the study in this research are population, sample, and sampling.In sampling, the writer considers that there is a distinction among second class grades (II a, II b, II c, II d) in the experience of learning English. The total of the sample is as in this table.

The Formulation of Research Sample

\begin{tabular}{|c|c|c|c|}
\hline No & Grade & Total Population & Total Sample \\
\hline 1 & II A & 30 & 7 \\
\hline 2 & II B & 30 & 7 \\
\hline 3 & IIC & 30 & 8 \\
\hline 4 & IID & 30 & 8 \\
\hline \multicolumn{2}{|c|}{ Total } & 120 & 30 \\
\hline
\end{tabular}




\section{The Technique of Data Collection}

In this study, the writer collects data as follows

Questionnaire

Questionnaire is printed question used to get information from respondent. It is the report of their private or other things they know (Kartono, 1990: 135).

\section{Observation}

Observation is intended to get more data to support the questionnaire. The purpose of the observation is to perceive the nature and extent of the significant interrelated elements with complex social phenomenon. It is to know about condition of school environment, teaching leaming process, and about the phenomenon which happens. This method is used to know about history, structure of school organization, the teacher and staff, the students, the school of SMU Muhammadiyah Salatiga as research subject.

Interview

Interview method is designed to verify the information obtained through questionnaire or to collect data by direct relation with information / face to face relation (Kartono, 1990: 170). Here, the writer asks the English teachers of the second year students to know the condition of the students and teachers themselves, to obtain the more accurate data of students' English achievement. Data about English students' achievement was taken from English grade point average of report of second year students of SMU Muhammadiyah Salatiga in the academic year of $2004 / 2005$. 


\section{Data Analysis.}

In order to conduct a good arrangement, the writer uses a statistic formula; further this formula is used to find out the influence of the classroom management toward students' English achievement. The writer analysis the research data as follows (Wapon, 1988: 369).

Calculating the score of classroom management.

$\mathrm{P}=\frac{\sum x}{N \times 100} \times 100 \%$

Calculating the score of students' English achievement.

$\mathrm{P}=\frac{\sum x}{N \times 100} \times 100 \%$

Product Moment Correlation Analysis.

$\mathrm{rXY}=\frac{\sum X Y-\frac{\left(\sum X\right)\left(\sum Y\right)}{N}}{\sqrt{\left\{\sum X^{2}-\frac{\left(\sum X\right)^{2}}{N}\right\}\left\{\sum Y^{2}-\frac{\left(\sum Y\right)^{2}}{N}\right\}}}$

\section{Discussion}

\section{Data Analysis}

There are two variables used by the writer to analyze whether there is or not a positive correlation between classroom management and students' English achievement. Those are Independent Variable (X) as Classroom Management and Dependent Variable (Y) as students' English Achievement. 


\section{First Analysis of Classroom Management}

The analysis is to find out the score of classroom management.

$$
\begin{aligned}
\Sigma \mathrm{X} & =2628 \\
\mathrm{~N} & =30 \\
\mathrm{P} & =\frac{\sum X}{N \times 100} \times 100 \% \\
\mathrm{P} & =\frac{2628}{30 X 100} \times 100 \% \\
& =\frac{2628}{30} \\
& =87.6 \%
\end{aligned}
$$

The score of classroom management of English teacher at SMU Muhammadiyah Salatiga according to the writer is high, $(87.6 \%)$.

Second Analysis of Students' English Achievement

This analysis will find out the score of students' English Achievement.

$$
\begin{aligned}
\sum \mathrm{Y} & =2160 \\
\mathrm{~N} & =30 \\
\mathrm{P} & =\frac{\sum Y}{N \times 100} \times 100 \% \\
\mathrm{P} & =\frac{2160}{30 \times 100} \times 100 \%
\end{aligned}
$$




$$
\begin{aligned}
& =\frac{2160}{30} \\
& =72 \%
\end{aligned}
$$

The score of students' English achievement of the second year students of SMU Muhammadiyah Salatiga is high, (72\%).

Third analysis of the Correlation of Classroom Management and Students' English Achievement.

This analysis is used to find out the correlation between classroom management and students' English achievement.

$\sum X \quad=2628$

$\sum \mathrm{Y} \quad=2160$

$\sum X^{2}=233566$

$\sum Y^{2}=159000$

$\sum X Y=190650$

$\mathrm{rXY}=\frac{\sum X Y-\frac{(\Sigma X)\left(\sum Y\right)}{N}}{\sqrt{\left\{\sum X^{2}-\frac{\left(\sum X\right)^{2}}{N}\right\}\left\{\sum Y^{2}-\frac{(\Sigma Y)^{2}}{N}\right\}}}$

$r X Y=\frac{190650-\frac{(2628)(2160)}{30}}{\sqrt{\left\{233566-\frac{(2628)^{2}}{30}\right\}\left\{159000-\frac{(2160)^{2}}{30}\right\}}}$ 


$$
\begin{aligned}
r X Y & =\frac{190650-\frac{5676480}{30}}{\sqrt{\left\{233566-\frac{6906384}{30}\right\}\left\{159000-\frac{4665600}{30}\right\}}} \\
& =\frac{190650-189216}{\sqrt{\{233566-230212.8\}\{159000-155520\}}} \\
& =\frac{1434}{\sqrt{(3353.2)(3480)}} \\
& =\frac{1434}{\sqrt{11669136}} \\
& =\frac{1434}{3416.01} \\
& =0.419
\end{aligned}
$$

From the calculation of the product moment correlation analysis, the writer obtains that the arithmetic $r$ is 0.419 . To know the significance of variable $\mathrm{X}$ to variable $\mathrm{Y}$; the arithmetic $r$ should be compared with table $r$ with the number of sample (30 students) and the level of siginificance 5\%. It proves that arithmetic calculation is higher than table $r$ because $r h$ is 0.419 while $r t$ is 0.361 There is a positive correlation between classroom management and students' English achievement. It can also be said that that better class management influences students' English achievement. 


\section{Conclusion}

There are conclusions that will be presented related to the problems of the study. The first will concern with classroom management, the second will concern with students' English achievement and the third will concem with the correlation between classroom management and students' English achievement.

Based on the result of the research, the writer concludes:

1. The classroom management of the English teachers of SMU Muhammadiyah Salatiga is fairly high. The result of this research shows that the score of classroom Management is $87.6 \%$.

2. The level of students' English achievement can be seen from the score level of students' English achievement. The result of this research shows that the score of students' English achievement of the second year students of SMU Muhammadiyah is $72 \%$. This is identified as the satisfactory category of achievement level of the most students.

3. There is positive correlation between classroom management and studnets' English achievement. Because $r h$ is higher than $r t$. It is proven by the result of the research showing that the score of $r h$ is 0.419 and $r t$ is 0.361 , so $r h>r t$.

4. Better classroom management influences better students' English achievement. 


\section{References}

S.L, Pasaribu and B, Simanjuntak. 1983. Proses Belajar Mengajar. Bandung: Tarsito.

Veron, F. Jones and Lovise, Jones. 1998. Comprehension Classroom Management. United States of America.

Richards, Jack and Lockhard, Charles. 1994. Reflective Teaching in Second Language Classroom. USA: Cambridge University Press.

Usman, Muh. Uzer. 1990. Menjadi Guru Profesional. Bandung: Remaja Rosda Karya.

Wapon, RonaldE. 1988. Pengantar Statistik. Jakarta: Gramedia

(Kartono Kartini. 1990. Metodologi Riset Sosial. Bandung: Manar Maju.

Witte, Stephen P. and Faighley, Lester. 1981. Coherence, Cohesion and Writing Quality. College composition and communication, 32, 189-204. 